\title{
CAPITAL AND SURPLUS UNDER THE NEW CORPORATION STATUTES
}

\author{
RAX GarRETT*
}

INTRODUCTION

The statutory treatment of capital and surplus during the first century of general business corporation statutes in the United States produced a great deal of confusion and litigation. The principal sources of difficulty seem to have been the use of terms that were susceptible of more than one meaning and the failure to define them in a technical or legal sense. In the last half century, and particularly during the last three decades, statutory revisors have sought to bring about a more precise statement of the rights and interests of stockholders in corporate capital and surplus. Their accomplishments have been commendable and provide the thesis of this article.

In early corporation statutes, the interests of stockholders were divisible into two categories-capital and surplus. The capital of a corporation was the amount that the proprietors agreed to invest in the enterprise and was measured by the aggregate par value of the shares of stock issued or susbcribed for. The courts soon imposed on this statutory concept the trust-fund doctrine, which regarded assets equal to the amount of capital as a trust fund for the protection of creditors. Whenever the assets were less than that amount, the proprietors were not entitled to make distributions to themselves; but whenever the assets exceeded that amount, the excess was regarded as surplus and was freely distributable to the proprietors, because it was necessarily derived from profits of the business. Since no particular assets were earmarked for creditors and there was no actual fund, the doctrine was nothing more than a restriction on the amount of assets that could lawfully be distributed to the proprietors. ${ }^{1}$ This was accepted as a rule of law, with statutory tolerance, for nearly a century.

The first serious effort to define capital in a legal sense and settle the controversy over the meaning of the term began with the introduction of shares without par value in I912. The aggregate par value of the outstanding shares was no longer the sole measure of capital, and capital represented by shares without par value could be expressed in dollars only in terms of the consideration received for them by the corporation. The later recognition of the right of a corporation to allocate only

- LL.B. 1916, Illinois Wesleyan University. Member of the Illinois bar.

${ }^{1}$ Ballantine and Hills aptly described the situation in their reference to "the misty metaphors of the so-called 'trust fund doctrine." See Ballantine and Hills, Corporate Capital and Restrictions Upon Dividends Under Modern Corporation Laws, 23 CaLIF. L. Rev. 229, 230 (1935). 
a portion of the consideration for no par value shares to capital created a need for a third category to represent the interests of stockholders. Surplus was no longer derived solely from profits of the business; it became a mixture of profits and a portion of the consideration contributed by stockholders. To separate the mixture into its component parts, surplus was divided into capital (or paid-in) surplus, representing a portion of the consideration received for no par value shares not allocated to capital, and earned surplus, representing profits. This occasioned the adoption of new terminology and refinements in the definition and use of the new terms. New rules were required for regulating the rights of stockholders in the three categories.

In addition, the concept of capital itself grew complex by innovations in the kinds and characteristics of capital stock that could be created. The authorized capital stock became divisible into classes and into series within a class having varying rights and preferences and having either par value or no par value. Various classes could be redeemed, converted, exchanged, or reclassified, and debt obligations could be converted into shares of capital stock. Dividends could be paid in cash, property, or shares of capital stock of the corporation. A corporation could purchase its own stock for retirement or resale. These and many other innovations required statutory recognition. A few states seized the opportunity to meet these innovations by liberalizing their laws and inviting enterprises to incorporate in their states. A competitive era ensued during which liberality was openly advertised in bids for new corporations, without regard for the locale of the business to be carried on.

The competitive era aroused the attention of other states and caused many of them to examine the limitations and restrictions of their own laws. Some states sought to modernize their laws by piecemeal amendments of existing statutes, but the results were seldom satisfactory and eventually led to complete revisions. Beginning with Ohio, which enacted an entirely new type of corporation statute in I927, twenty-four states and the District of Columbia have completely revised their general business corporation statutes. ${ }^{2}$ The past thirty years, then, has been an era of modernization. The motives behind modernization have been the same in every instance-to offset the competition offered by other states by eliminating obsolete provisions of earlier statutes and creating a healthier climate for modern business enterprises that would prefer to incorporate locally.

Dưring this era of modernization, the Committee on Corporate Laws of the American Bar Association, observing the need of statutory revisors for an adequate drafting guide, undertook the preparation of a Model Business Corporation Act. ${ }^{3}$

\footnotetext{
- Subsequent to the Ohio statute of 1927 , revised statutes were enacted in the following jurisdictions: Louisiana (1928), Indiana, Idaho, and Tennessee (I929), Arkansas, California, Michigan, and Pennsylvania (1931), Illinois, Minnesota, and Washington (1933), Kansas (1939), Nebraska (1941), Missouri (1943), Kentucky (r946), Oklahoma (1947), Maryland and Wisconsin (1951), Oregon (1953), District of Columbia (1954), North Carolina and Texas (1955), Virginia (1956), North Dakota (1957), and Colorado (r958).

${ }^{3}$ Commitree on Corporate laws, American Bar Associatton, Model Business Corporatron Act (1957) contains the most recent version.
} 
The first complete edition was published in 1950, somewhat revised in 1953, and supplemented in 1955 and 1957. The Model Act was not proposed as a uniform law; that had been tried by the Commissioners on Uniform State Laws in 1928, without much success. ${ }^{4}$ Neither was it regarded by its authors as reform legislation. It was conceived as an organized selection of principles found in existing statutes, with one possible exception-the introduction of certain accounting techniques in the treatment of capital and surplus designed to render these important features more precise.

Since 1950, the Model Act has been credited as the principal source of six of the new statutes-viz., the Wisconsin Business Corporation Law (195r), the Oregon Business Corporation Act (1953), the District of Columbia Business Corporation Act (r954), the Texas Business Corporation Act (1955), the Virginia Stock Corporation Act (I956), and the North Dakota Business Corporation Act (I957). It has also been an influential factor in the Maryland General Corporation Law (195I) and the North Carolina Business Corporation Act (I955), and in recent amendments pertaining to capital and surplus in the Ohio General Corporation Law (originally enacted in 1927) and the Pennsylvania Business Corporation Law (originally enacted in I93I).$^{5}$ Since the ten revisions just mentioned represent the most recent expressions of legislative treatment of capital and surplus, they have been selected as the "new statutes" for the purposes of this article.

Each of the new statutes seeks, in its own way, to clarify the statutory law relating to capital and surplus, to avoid the confusion and ambiguities of the past, and to provide standards for the guidance of corporations in matters involving the concepts of capital and surplus. These objectives are accomplished by defining certain essential terms and then using them where appropriate in the defined sense. Remembering that business corporation statutes are applicable to corporations of every conceiyable size, their provisions must be general in nature and merely set forth the basic rules to be followed in any given situation. The new statutes present the rules governing capital and surplus in a more scientific and flexible manner than existed for the past century and a quarter. Perhaps they, too, will require construction and interpretation by the courts and legal writers, but no better approach has yet been found.

The terms used in the new statutes are not necessarily new to statutory law or to accounting, although many are new to these jurisdictions. In many modern

The Uniform Business Corporation Act is published at 9 U.L.A. Ix5 (1957). Subsequent to its original adoption, the Commissioners on Uniform State Laws changed the name of the Act to "Model Business Corporation Act." It should not be confused with the Model Act referred to in the text of this article.

¿See D.C. Code ANn. $\$$ 29-90I-29-956 (Supp. I956); MD. ANn. Code art. 23, §§ I-r27 (x95I); N.C. Gen. Stat. $\$ 5$ 55-I-55-175 (Supp. I955); N.D. Laws 1957, c. 102, $\$ \$$ 1-144; OHIo REv. CodE ANN. \$\$ I701.0r-r70r.99 (Page Supp. 1956); ORE. Rev. STAT. \$ 57.002-57.994 (Supp. 1955); PA. STAT. ANN. tit. 15, $\$$ 2852-1-2952-1202 (Supp. I956); TEX. Bus. CoRp. ACT art. I-OI-II-0I (1956); VA. Code ANN. $\$ \$$ 13.I-13.I-I32 (Supp. 1956); WIs. Stat. $\$ \$$ r80.01-180.97 (I955). In addition, Colorado recently adopted a new statute substantially identical with the Model Act, which does not become effective until January $x$, 1959 . 
statutes, the controversial terms of capital, capital stock, surplus, earnings, and profits, that are found in earlier statutes, have been replaced by stated capital and various kinds of surplus. Impairment of capital has become impairment of stated capital. Insolvency and treasury shares have been expressly defined in many statutes. The term capital stock has largely disappeared in favor of the simple term "shares," although lawyers schooled in other days find this change in terminology difficult to remember on occasion.

The Model Act proposes that the interests of shareholders be identified in three categories: stated capital, capital surplus, and earned surplus. It then sets out the manner in which the amounts in these categories are to be determined and the uses that may be made of them. A series of defined terms is the key to the proposed system - "net assets," "stated capital," "surplus," earned surplus," "capital surplus," "treasury shares," and "insolvent." With the exception of insolvency, the definitions of these terms can be reduced to the following mathematical formula: beginning with total assets, deduct total debts (and treasury shares if carried as an asset), and the remainder is net assets; deduct stated capital from net assets, and the remainder is surplus; deduct earned surplus from total surplus, and the remainder is capital surplus.

The theory of the Model Act is that net assets will provide for the claims of creditors ahead of shareholders; that stated capital will provide for the permanent investments of shareholders; that capital (or paid-in) surplus will represent, in the first instance, a portion of the investments of shareholders that is less permanent but subject to special protective rules; that earned surplus will represent the accumulated and undistributed profits; that upstream transfers from earned surplus to capital surplus or stated capital should be largely discretionary with the board of directors, but downstream transfers should generally require the approval of shareholders; and that the whole purpose of the formula and restrictions accompanying it is to state when and under what circumstances corporate assets can be distributed to the shareholders. All of the new statutes employ the same theory, and variations among them reflect local preferences as to details, rather than departures from basic theory.

The drafting principles followed in the new statutes merit some explanation. The statutory revisors in any jurisdiction are faced with the problem of selecting what features of existing law should be preserved in the light of judicial construction, public policy, and familiarity among members of the local bar. The prime question asked by legislators and practitioners is: How does the proposed statute change the existing law? In answering this question, the revisors must be prepared to demonstrate the value of every important proposed change. Evaluation of a proposed change depends, in large measure, on the personal views and experiences of the revisors and the degree of objectivity with which they have approached their task. Each of the new statutes, therefore, reflects a combination, and often a compromise, of local precedents, personal views, and the study of a variety of available

${ }^{\circ}$ See Model Business Corporation Act 52. 
alternatives, among them the several drafts of the Model Act. The result has produced a customary lack of uniformity, but a growing similarity of principles.

In discussing the treatment of capital and surplus in the new statutes, the sequence of defined terms used in the Model Act will be followed. Some of the differences among the new statutes themselves are regarded as relatively unimportant and will be ignored. Owing to differences in organization of material, moreover, it is sometimes difficult to identify their differences in principle. If errors occur below, they should be attributed to the fact that all of the new statutes are foreign to the writer's own state of Illinois.

\section{Net Assets}

The term "net assets" is in common use in corporation statutes as the minimum amount of assets that must be protected against distribution among the shareholders in order to cover the claims of creditors; but few statutes have seen fit to define it, on the theory, no doubt, that its meaning is implicit.

In preparing the Model Act, the sponsoring committee believed that it would be useful to define the term and suggested the following precise definition: "Net Assets' means the amount by which the total assets, excluding treasury shares, exceed the total debts of the corporation." Obviously, total assets are related to value; but in as much as directors are entitled under the Model Act to rely in good faith on book values, ${ }^{8}$ there was no need to specify how the assets were to be valued. If the directors do not rely on book values in good faith, then they must substitute some other value and are responsible for the value adopted by them. The Committee debated at length the choice between debts and liabilities as elements of the definition. It chose debts as the more certain term, because they are ordinarily fixed as to liability and liquidated as to amount, whereas liabilities connote something more in the way of contingencies and speculations. The term net assets as defined in the Model Act is equivalent to the balance sheet concept of net worth and includes stated capital, surplus, and surplus reserves, which are in no sense liabilities. Since net worth appears on the liability side of a balance sheet, there was some concern over the possible impression that shareholders' interests would be regarded as liabilities, when, in fact, the term net assets was intended to represent the aggregate of their interests.

The term is used in the Model Act in two connections. The board of directors is authorized to make a distribution to shareholders in partial liquidation out of stated capital or capital surplus, subject to certain restrictions, among them a provision that the distribution must not reduce the remaining net assets below the voluntary liquidation preference of preferential shares. ${ }^{9}$ Also, no redemption or purchase of redeemable shares can be made which would reduce the net assets:

${ }^{7}$ Ibid.

${ }^{8} I d . \S 43$.

${ }^{\circ} I d . \$ 4 \mathrm{r}$. 
below the amount payable to the holders of shares having equal or prior rights upon involuntary dissolution. ${ }^{10}$

The definition in the Model Act was available to the revisors of all of the new statutes. Their reactions furnish a good illustration of the diversity of thought on a relatively simple treatment of the subject. Undoubtedly all of the revisors had the same principle in mind, but here is what happened.

Wisconsin, Oregon, Texas, and North Dakota adopted the definition and use the term in the same manner as in the Model Act. ${ }^{11}$ Maryland does not define net assets, but uses it in restricting a corporation's right to purchase or redeem its redeemable shares or to distribute capital surplus. ${ }^{12}$ As to the former, something called "net asset value" is allocated to the several classes of shares in the order of seniority, and the purchase price for redeemable shares must not exceed the net asset value of such shares. As to the latter, capital surplus arising from a reduction of stated capital is distributable to shareholders only if the remaining net assets equal the voluntary liquidation preferences of shares having senior rights in liquidation. The manner of determining and allocating net asset value is left to inference. Some indication is found in the term "insolvency," which is deemed to exist if the debts exceed the assets "taken at fair valuation." 13 The District of Columbia purports to define net assets, but only for the purpose of excluding treasury shares in determining the right of a corporation to purchase its own shares and to declare and pay dividends, and in determining the liability of directors. ${ }^{14}$ Pennsylvania defines net assets as the amount by which total assets exceed total liabilities exclusive of stated capital and surplus. ${ }^{15}$ "Assets" is defined as including all property and rights of every kind, ${ }^{16}$ which adds little to the ordinary meaning of assets; but there is no definition of "liabilities." It is evident that the Pennsylvania revisors found it necessary to negative the idea that stated capital and surplus might be considered to be liabilities. Ohio provides no separate definition of net assets, but uses the term in defining surplus as the excess of assets over liabilities. ${ }^{17}$ Virginia, likewise, omits the definition, but the term is used without other identification in connection with the computation of surplus and the redemption or purchase of redeemable shares. ${ }^{18}$

The most elaborate definition of net assets occurs in North Carolina, which substitutes liabilities for debts and defines both assets and liabilities in a unique manner. ${ }^{19}$ The test of inclusion or exclusion of assets and liabilities is one of reference

${ }^{10} I d . \$ 60$.

11 WIs. Stat. $\$ 180.02(9)$ (1955); Ore. Rev. Stat. $\$$ 57.004(8) (Supp. 1955); Tex. Bus. CoRp. Acr art. 1.02(10) (1956); N.D. Laws 1957, c. 102, $\$ 2(9)$.

${ }^{12} \mathrm{MD}$. ANN. CODE art. 23, $\$ 32(\mathrm{~b})(\mathrm{r}), 36(\mathrm{~b})$ (195r).

${ }^{13} \mathrm{Id}$. $\$ 32(\mathrm{c})$.

${ }^{14}$ D.C. CODE ANN. $\$ 29-902$ (L) (Supp. 1956).

15 PA. Stat. Ann. tit. 15, 2852-2 (Supp. 1956).

${ }^{10} \mathrm{Id}$. $\S 2852-2$.

${ }^{27}$ Oho Rev. Code ANn. $\$$ r7or.32(A) (Page Supp. 1956).

${ }^{18}$ VA. CODE ANN. $\$$ I3.I-2(h).

${ }^{19}$ N.C. Gen. Stat. \$ 55-2(2) and (7) (Supp. r955). 
to accounting procedures. The phrase used is "in accordance with generally accepted principles of sound accounting practice," the origin of which is unknown to the writer of this article. In the area of corporate finance, a reference to generally accepted accounting principles is in common use and relates to existing standards of the accounting profession; but the addition of "sound accounting practice" qualifies the standard by the injection of a personal judgment factor. An accounting principle may be generally accepted, but regarded as unsound by individual accountants. It is axiomatic that accountants, as do lawyers, frequently disagree on both principles and practices, and directors may be obliged to decide between conflicting views at their peril. The most significant result of these definitions is the abandonment of the corporate books as to the existence of net assets. Assets and liabilities are to be determined on the basis of what should be on the books, whether or not so recorded, and directors are not exonerated if they rely on the book value of assets, even in good faith. Their exoneration depends upon the dual accounting tests of generally accepted principles and sound accounting practice.

The North Carolina statute also superimposes a "fair present value" test in lieu of net assets in connection with dividends and purchases and redemptions of shares. ${ }^{20}$ Such transactions are prohibited if the liabilities exceed the fair present value of the assets. In case of a distribution in partial liquidation, the fair present value must be at least equal to twice the amount of liabilities. The statute is silent on how fair present value is to be determined. These limitations impose a duty on the directors to appraise asset values before such transactions can be authorized with impunity.

It is questionable whether these elaborate refinements in the North Carolina statute contribute to the improvement of statutory law or facilitate corporate practices. They appear to create many unnecessary problems of construction and application.

However the new statutes may have defined or used the term, they recognize the necessity of confining distributions to shareholders to the excess of assets over the claims of creditors. This achieves the same result sought in the early trust-fund doctrine, without the fictions of a trust or a fund. Attempts to define assets and debts or liabilities in terms of valuation are futile, because the generality of the words employed also requires definition. It seems better to leave the responsibility with the directors and rest their liability upon good faith reliance on the corporate books or the representations of public accountants or appropriate corporate officers.

II

\section{Stated Capital}

After creditors are protected by net assets, however defined or used, any excess must satisfy the first category of shareholder interests before there is any surplus. This category is stated capital-a term that came into use with the advent of shares without par value. Such shares can be expressed in dollars on the corporate books

${ }^{20} I d . \$ \$ 55-50(\mathrm{c})(2)$ and $55-52(\mathrm{e})(2)$. 
only by reference to the amount of consideration received for them. Thus, stated capital became the conventional term to express the aggregate of the par value of shares having a par value and the consideration received for shares having no par value. Later, stated capital was modified to exclude that part of the consideration for no par value shares that has been allocated to capital (or paid-in) surplus.

In most modern statutes, stated capital is an elaborate successor of the older term "capital" and serves a substantially similar purpose. One outstanding exception is Delaware, which has not seen fit to change its terminology, even though shares without par value and the allocation between capital and surplus have long been recognized in that state. ${ }^{21}$ In many respects, however, stated capital in the new statutes is conceptually quite different from its predecessor. One of its chief characteristics is flexibility; it is subject to many changes that were unavailable when par value was the sole measure of capital. In the modern sense, it must reflect the basic elements of shares that have been issued with and without par value and the effect of issuing a share dividend, or the purchase or redemption of issued shares, or the conversion or exchange of issued shares, or the capitalization of surplus without the issuance of shares, or the reclassification of outstanding shares by charter amendment; also the possibility of distributing some of the assets in partial liquidation, and the possibility of effecting a reduction for other purposes by the vote or consent of shareholders-all of these with a protecting eye on the rights of preferred shares where more than one class of shares exists.

The component parts of stated capital are identified in some of the new statutes in the form of a definition; in others, as a formula for the determination of the amount. Regardless of the form, the component parts may be classified as the basic elements, authorized increases, and authorized deductions. There is a marked similarity in all of the new statutes in the principles applied to the determination and use of stated capital; but there are differences in detail that cannot adequately be discussed in a few general statements. Therefore, the subject will be broken up according to the foregoing classification of component parts.

\section{A. Basic Elements}

In all of the new statutes, as in the Model Act, the basic elements of stated capital are determined in relation to par value shares and some or all of the consideration for shares without par value.

As to par value shares, the Model Act recognizes that it would be a flagrant violation of tradition to include them in stated capital at less than par. ${ }^{22}$ There is an obvious representation that par value symbolizes the amount invested in the corporate enterprise. Very few statutes permit the issuance of such shares at a discount, and none of the new statutes expressly does so except North Carolina. ${ }^{23}$ Yet, all of them recognize that the issuance and sale of shares may involve expenses and com-

"2 Dex. Code ANN. tit. 8, $\$ 54$ (1953).

22 Model Business Corporation ACt $\$ \$ 2,17$, and 19.

${ }^{23}$ N.C. GEN. STAT. $\$ 55-46$ (c)(I) (Supp. 1955). 
pensation to someone. For that reason, they provide that the payment or allowance of reasonable expenses and compensation may be made out of the consideration received without rendering the shares not fully paid. In North Carolina, this provision is described as a discount and required to be carried in a special account, but it is not a discount in the usual meaning of the word.

All of the new statutes, as well as the Model Act, permit the sale of par value shares at a premium. It is a common occurrence in today's market for the par value to be very low in relation to the sale price. Under most of the new statutes, any excess over par becomes capital surplus (paid-in surplus in the District of Columbia). Of course, there are exceptions. Ohio requires the entire consideration to be included in stated capital, unless the incorporators, shareholders or directors have specified that only a portion thereof shall be stated capital. ${ }^{24}$ Virginia requires the entire consideration to be stated capital, except as otherwise provided in case of conversion or exchange. ${ }^{25}$ This provision in Virginia would seem to permit stated capital to represent less than par, although not expressly so stated. With these few exceptions, par value is both the minimum and the maximum stated capital for par value shares under the new statutes.

The situation in respect of shares without par value involves neither premium nor discount in a sense comparable to par value shares. The board of directors is generally permitted to fix the consideration for which shares without par value are to be issued, and all of it becomes stated capital, with one exception-namely, the right of directors to allocate a portion thereof to capital (or paid-in) surplus. Among the new statutes, the permissible allocation varies as to the time it must be made and the percentage that can be allocated to surplus. A time lag before allocation will allow for inventory or appraisal where the consideration is in the form of property. Prior to the 1957 supplement, the Model Act permitted an allocation of not to exceed twenty-five per cent within sixty days after issuance of the shares. ${ }^{26}$ This suggestion was adopted in Wisconsin, Oregon, Texas, Virginia, and North Dakota. ${ }^{27}$ In Virginia, however, the allocation may be varied by the contract of subscription. In the other new statutes, the allocation is unrestricted as to amount, but must be made at or prior to the issuance of the shares. Notwithstanding the broad authority to make such an allocation, in all of the new statutes, as well as in the Model Act, shares without par value having a liquidation preference are protected by limiting the amount that can be allocated to surplus to the excess of the consideration received over the liquidation preference of such shares. In most cases, this limitation refers to the preference in voluntary liquidation, while in others, the reference is to involuntary liquidation; the choice depends upon the personal views of the statutory revisors.

26 Ohio Rev. Code ANv. $\S$ I701.30(B)(I) (Page Supp. 1956).

${ }^{20}$ VA. Code ANn. $\S$ 13.T-18 (Supp. 1956).

${ }^{20} \mathrm{C}$. Model Business Corporation ACt $\$$ ig.

${ }^{97}$ Wis. Stat. $\$ 180.16(2)$ (r955); OrE. Rev. Stat. $\$ 57.11$ I (2) (Supp. 1955). Tex. Bus. Corp. Act art. 2.17(B) (1956); VA. CODE ANN. \$ 13.I-18 (Supp. 1956); N.D. Laws 1957, c. 102, $\$ 18$. 
The amounts to be included in stated capital in respect of shares with or without par value are confined to issued shares, except in Maryland and North Carolina and apparently in Ohio. ${ }^{28}$ The full agreed consideration for shares subscribed for is included in Maryland and North Carolina, even though not fully paid, and the cancellation of subscriptions automatically reduces stated capital. In Ohio, subscriptions are not expressly included, but their cancellation effects a reduction, the logic of which is not apparent. The inclusion of unpaid subscriptions seems to be a relic of early laws, where an agreement to invest in a corporation was part of its legal capital. Also, it is possible that the status of subscriptions posed a problem as to the manner in which they should be carried on the corporate books. If so, it is suggested that the payments already received are presumably among the assets of the corporation; the unpaid amounts are also assets in the form of subscriptions receivable; and the offsetting account on the liability side of the balance sheet can be shown as shares subscribed for but not issued. If the subscriptions are canceled, the receivables and the liability account can be canceled, and the payments received would more logically become surplus than stated capital, because they constitute something in the nature of a windfall to the corporation. There seems to be no compelling reason to include partially-paid subscriptions in stated capital; only issued shares should be represented in the category that reflects the permanent investments of shareholders.

The basic elements of stated capital, then, can be described as the aggregate par value of all par value shares that have been issued and the aggregate consideration received for all shares without par value that have been issued, less portions of the consideration received for shares without par value allocated to some surplus account, with the rather minor exceptions above noted in the new statutes of Maryland, North Carolina, Virginia, and Ohio.

\section{B. Increase by Share Dividends}

Perhaps the most frequent increase in stated capital accompanies the payment of a share dividend. Where the dividend is paid in authorized but unissued shares, a new issue is involved and the new shares should be reflected in stated capital in the same manner as other issued shares-i.e., at par value in case the shares have a par value and at a value fixed by the board of directors in case the shares are without par value. Where the dividend is paid in treasury shares, however, a new issue may not be involved and stated capital is not necessarily increased.

Since the payment of a share dividend out of authorized but unissued shares is in lieu of a distribution of surplus in cash or property, and no other consideration is received by the corporation, surplus should be reduced by a transfer of the amount of the dividend to stated capital. All of the new statutes, as well as the Model Act, ${ }^{29}$ require such a transfer at par or at a value fixed by the board of

${ }^{28}$ Mo. COde ANn. art. 23, $\$ 2$ (12) (I95x); N.C. Gen. StAt. $\$ 55-47$ (a) (Supp. 1955); OHo Rev. Code ANN. $\$ \$ 1701.30(A)$ and I701.31(B) (Page Supp. 1956).

${ }^{29}$ Model Business Corporation Act $\$ 40$. 
directors, dependent upon whether payment is made in shares of par value or without par value.

Payment of a share dividend out of treasury shares should increase stated capital only if stated capital is automatically reduced by the mere reacquisition of shares; in fact, when this happens, they are not treasury shares in a technical sense. Under most of the new statutes, as in the Model Act, ${ }^{30}$ reacquired nonredeemable shares are not automatically canceled, and while they retain the status of treasury shares, they remain as issued shares and stated capital is not reduced until they are canceled or retired. Consequently, when reissued as a share dividend, stated capital is not increased because it already reflects such shares. Differences are noted in North Carolina and Ohio. ${ }^{31}$ North Carolina permits a distribution of treasury shares to be made, but expressly forbids it to be described as a dividend. In Ohio, stated capital is reduced when shares are reacquired and must be restored by a transfer of surplus when reissued as a share dividend. It is not clear that treasury shares can be used for the payment of a share dividend in Maryland and the District of Columbia, ${ }^{32}$ but all of the other new statutes expressly permit it.

\section{Increase Without Change in Shares}

Under some circumstances, it may be desirable to increase stated capital by a transfer from surplus unaccompanied by the issuance, redemption, exchange, cancellation, or conversion of shares. A simple example would be an increase in the par value of outstanding shares by charter amendment. In order to bring stated capital into line with the increased par value, a transfer from surplus is inevitable, because no additional consideration is paid in to the corporation. Unless the charter amendment effects the increase, a resolution of the board of directors should be adequate for the purpose.

All of the new statutes, as does the Model Act, ${ }^{33}$ make provision for an increase in this manner. The above example is not appropriate in North Carolina, however, where a transfer from surplus is limited to shares without par value. ${ }^{34}$

In authorizing a transfer of surplus under these provisions of the new statutes, the board of directors may designate the class of shares with respect to which stated capital is increased, except in Ohio, where a designation appears to be mandatory, ${ }^{35}$ and in Maryland, where no mention of the matter appears. An increase in respect of a particular class may be an important step in preparation for a distribution to shareholders or other transaction requiring the maintenance of the liquidation preference of a class of par value shares, where only par value is required to be included in stated capital when the class was originally issued.

${ }^{80} 1 d . \S 6 \mathrm{r}$.

${ }^{31}$ N.C. Gen. Stat. $\$ 55-5 I$ (d) (Supp. 1955); OHIo Rev. Code ANn. $\$ \$$ I70I.3I(A) and I701.33(B) (Page Supp. 1956).

${ }^{33}$ MD. ANN. Code art. $23, \$ 332(\mathrm{~g})$ and $37(\mathrm{a})(4)$ and (5) (x95I); D.C. Cone ANN. $\$ 29-917$ (c) and (d) (Supp. r956).

${ }^{33}$ Model Business Corporation Act $\$ 19 . \quad{ }^{34}$ N.C. Gen Stat. $\$ 55-47$ (4) (Supp. 1955).

${ }^{35}$ Ohto Rev. Code Ans. \$170r.30(A) and (C) (Page Supp. I956). 


\section{Decrease by Cancellation of Shares}

So long as stated capital represents all issued shares, any decrease of issued shares should result in a decrease of stated capital. Such a decrease can be brought about in several ways. Let us first consider a decrease by redemption or purchase of redeemable shares.

The right of a corporation to redeem its outstanding redeemable shares is as old as the right to issue such shares in the first instance. All modern corporation statutes recognize that redeemable shares can be created, and it is an incident of their creation that they can, and sometimes must, be called for redemption at stated prices, which may vary as time goes on. Conditions and restrictions are usually specified in the charter documents creating the shares, but there are legislative restrictions in all of the new statutes.

In the new statutes, restrictions on the redemption and purchase of redeemable shares are basically related to insolvency and the protection of shares of equal or senior priority; but there is considerable variation in the language used to express them. In the Model Act, for example, the protection for creditors is found in the provision that redeemable shares cannot be purchased or redeemed if the corporation is insolvent or would be rendered so by the transaction; ${ }^{36}$ and insolvency is defined as inability to pay debts as they become due in the usual course of business. ${ }^{87}$ In Texas, a similar idea is expressed as a condition that no reasonable ground exists for believing that the corporation will be unable to satisfy its debts and liabilities when they fall due-a belief instead of a fact. ${ }^{38}$ The choice of language in other jurisdictions depends somewhat on the existence or absence of insolvency as a defined term.

The most common protection for other shares is that the purchase or redemption cannot be made if it would reduce net assets below the liquidation preference of shares of prior or equal classes. For this purpose, as well as for the insolvency test, assets are subject to "net asset value" in Maryland and "fair present value" in North Carolina. ${ }^{39}$

In a number of the new statutes, a purchase of redeemable shares is expressly limited to the current redemption price, as it should be. In Maryland, however, a purchase is limited to the lower of the current redemption price or the net asset value attributable to the class after marshaling net asset values according to the seniority of the existing classes, although an exception to the net asset value is recognized if a sinking. fund or other charter provision requires otherwise. ${ }^{40}$ In North Carolina, a purchase or redemption is not authorized unless all accrued dividends on senior classes have been paid, or, if in default, notice of the proposed transaction is given to all holders of the class by adequate publicity. ${ }^{41}$

${ }^{36}$ Model Business Corporation ACt $\$ 60 . \quad{ }^{37} I d . \S 2$.

${ }^{38}$ T'Ex. Bus. Corp. ACt art. 4.09(A)(2) (1956).

${ }^{30}$ MD. ANN. CODE art. 23, $\$ 32$ (b) (I) (I95I); N.C. Gen. STAT. $\$ 55-52($ e) (2) (Supp. I955).

${ }^{10} \mathrm{Mo}$. ANN. CoDe art. 23, $\$$ 32(b)(I) (195I).

${ }^{11}$ N.C. Gen. Stat. \$55-52(f) (Supp. 1955). 
The effect on stated capital of the redemption or purchase of redeemable shares is as follows under the new statutes: In Maryland and Ohio, the shares purchased or redeemed are effectively retired without further corporate action and stated capital is reduced by the amount then represented by the retired shares. ${ }^{42}$ The same result is achieved in the District of Columbia upon the filing of an official statement if the charter provides that such shares shall be canceled and not reissued. ${ }^{43}$ In Virginia, North Carolina, and Pennsylvania, further action by the board of directors is required to effect a retirement of the shares, and the filing of an official statement or certificate is required before stated capital is effectively reduced. ${ }^{44}$ In the other states, as in the Model Act, ${ }^{45}$ the redemption or purchase constitutes a cancellation or retirement of the shares, but stated capial is not reduced until an appropriate official certificate or statement is filed. These official filings give public notice to creditors and others that stated capital has been reduced in the manner stated.

Turning now to nonredeemable shares, the general right of a corporation to acquire and dispose of its own shares has developed slowly over the years. It is presently recognized in all modern statutes, but there are legislative restrictions in the new statutes that are quite varied. These restrictions commonly consist of an enumeration of the authorized purchases that are exempt from certain restrictions, protective provisions for the benefit of creditors and other shareholders, and the measure of the amount that can be devoted to the purpose.

Early criticism of the practice of a corporation purchasing its own nonredeemable shares has resulted in at least seven specific categories in which a purchase is recognized in the new statutes, as follows: (I) elimination of fractional shares; (2) collection or compromise of debts due the corporation; (3) payment to dissenters; (4) repurchase of shares from employees; (5) release or settlement of subscriptions; (6) carrying out of an agreement with shareholders; and (7) authority granted by charter or a vote of shareholders. The first category is found in all of the new statutes except in Virginia. The second and third categories are in all of the new statutes. The fourth category is found in North Carolina. ${ }^{46}$ The remaining categories are found only in Ohio. ${ }^{47}$ Purchases of shares in these categories are not dependent upon the existence of surplus as a source of funds.

The problem of fractional shares commonly arises in connection with share dividends, split-ups, rights to subscribe to additional shares, conversions, and exchanges. The elimination of fractions by purchase has largely been replaced in modern practice by the issuance of scrip, cash payments in lieu of fractions, or a sale of the shares represented by all of the fractions and distribution of the proceeds

\footnotetext{
${ }^{\circ}$ MD. ANn. Code art. 23, $\S \S 33$ (a) (I95I); Ohro Rev. Code ANn. $\S$ I70I.36(B) (Page Supp. 1956).

${ }^{43}$ D.C. CODE ANN. $\$ 29-924$ (a) (Supp. 1956).

4 VA. CODE ANN. $\S 13.1-63$ (Supp. I956); N.C. Gen. Stat. $\$ 55-48($ c) and (d) (Supp. 1955); PA. STAT. ANN. tit. 15, $\$ 2852-705$ (Supp. x956).

${ }^{46}$ Model Bustness Corporation Act $\$ 6 \mathrm{~T}$.

${ }^{40}$ N.C. Gen. Stat. $\$ 55-52(4)$ (Supp. 1955).

${ }^{47}$ Ohio Rev. Code ANN. $\$ \S$ 170r.35(A)(3), (5), (7) and (9) (Page Supp. 1956).
} 
among those otherwise entitled thereto. The amount involved is usually too small for great concern. Sometimes debts due a corporation can be collected or compromised only by taking over the shares belonging to the debtor; if the corporation could not acquire the shares, the debts might become a total loss. Where dissenters are paid the value of their shares in cases of merger, consolidation, sale of assets, or otherwise, the shares are technically reacquired by the corporation; and the right to reacquire is commensurate with the corporation's obligation to pay. A release or settlement with subscribers as to their unpaid subscriptions results in the acquisition of the shares subscribed for only where partially-paid shares have been issued and are included in stated capital, as in Ohio $;^{48}$ in most instances, however, it would be regarded merely as a release of subscription. A repurchase of shares from employees is appropriate only where it is a condition of some share-purchase plan available to them. A repurchase of shares from shareholders obviously refers to a restricted share transfer agreement and should be recognized if enforceable against the corporation. Charter authority or approval by the requisite percentage of shareholders needs no explanation.

Protection for creditors is afforded by forbidding purchases when the corporation is insolvent or would be rendered insolvent by the transactions, or by some kindred measure of financial condition. Where insolvency is defined, as in the Model Act, ${ }^{49}$ the use of the term is adequate, but some of the new statutes use more elaborate language, such as: when there is reasonable ground to believe that the corporation is insolvent or would be rendered insolvent or its assets are less than its debts (Texas) $;^{50}$ or when there is reasonable ground to believe that the corporation will be unable to meet its obligations as they mature in the ordinary course of business (North Carolina) $;^{51}$ or when the liabilities exceed the fair present value of its assets (North Carolina)..$^{52}$

Protection for other shareholders is afforded by such restrictions as these: when the aggregate liquidation preference of shares having prior or equal rights exceeds the net assets (North Carolina) ${ }^{\mathbf{5 3}}$ or when the remaining net assets would be less than the voluntary liquidation preferences of the preferred shares (Pennsylvania) $;^{54}$ or when there are unpaid accrued dividends or dividend credits on preferred shares (North Carolina, but inapplicable when the purchases are exempt as above noted).$^{65}$

Except in case of purchases described above as exempt from certain restrictions, the right to purchase and dispose of nonredeemable shares is generally accorded to corporations within amounts measured by the existing surplus. This is justified on the theory that it may be more beneficial to the shareholders for the corporation to repurchase some of its shares out of surplus, and thus increase the interests of the

${ }^{18} \mathrm{Id}$. $\$$ I70I.3I(B).

${ }^{51}$ N.C. Gen. Stat. $\$ 55-52$ (e)(I) (Supp. 1955).

${ }^{29} I d$. $\S 55-52(e)(2)$.

${ }^{49}$ Moder Business Corporation Act $\$ 2$.

${ }^{52}$ PA. Stat. ANN. tit. 15, $\$ 2852-701$ (F)(2) (Supp. 1956).

${ }^{85}$ N.C. Gen. Stat. $\$ 55-52$ (c)(4) (Supp. 1955). 
remaining shareholders, than to distribute the surplus or retain it in the business. In most of the new statutes, as in the Model Act, ${ }^{58}$ earned surplus is the primary measure of the amount and is restricted so long as the reacquired shares are held in the treasury. The similar use and restriction of capital surplus is recognized in the Model Act and in several new statutes, but frequently rests upon charter authority or approval by a prescribed percentage of shareholders. In Texas, a special kind of surplus, called "reduction surplus," is also available. ${ }^{57}$ Pennsylvania illustrates certain limited instances permitting stated capital to be so used. ${ }^{58}$ Ohio defines and uses the term surplus as the excess of assets over liabilities plus stated capital; ${ }^{59}$ but, instead of using surplus as the measure of the right, goes to the trouble of providing that a corporation shall not purchase its own shares if, after such purchase, its assets would be less than its liabilities plus stated capital. ${ }^{60}$ The District of Columbia elaborately prohibits a purchase when the corporation's net assets are less than the sum of its stated capital, paid-in surplus, appreciation surplus, and any surplus arising from surrender to the corporation of any of its shares, or when by so doing its net assets would be reduced below that sum. ${ }^{61}$

When a corporation has purchased its own nonredeemable shares, they become treasury shares, except in Ohio, where the shares are deemed to be retired and stated capital is automatically reduced by the amount then represented by such shares. ${ }^{62}$ Treasury shares, on the other hand, have no effect on stated capital unless and until they are canceled or retired, in which event stated capital is reduced by the amount then representing the shares. There is considerable variation in the manner of accomplishing the cancellation and reduction. Many of the new statutes, and the Model Act, ${ }^{83}$ permit the cancellation by resolution of the board of directors, and the reduction of stated capital is effected by the official filing of a statement or certificate of reduction. Under other statutes, the official filing is not essential to the reduction.

All of the foregoing statements of rights and procedures relating to the purchase of shares and reduction of stated capital are necessarily qualified to the extent that they may be the subject of special authority and restrictions in a corporation's own charter documents.

\section{E. Reduction by Partial Liquidation}

Under some circumstances, there is no cogent reason why a corporation should be required to retain all of its assets until final liquidation and dissolution. Accordingly, the Model Act ${ }^{84}$ and several of the new statutes permit a distribution of a portion of

"o Model Business Corporation Act $\$ 5$.

${ }^{67}$ TEx. Bus. CoRp. ACT arts. I.02(A)(14) and 2.03(D) (1956).

${ }^{6 s}$ PA. Stat. ANN. tit. 15, $\$ 2852-701$ (Supp. 1956).

${ }^{50}$ Orto Rev. Code AnN. $\$$ I701.32(A) (Page Supp. 1956).

${ }^{\circ 0} \mathrm{Id}$. I701.35(B).

${ }^{61}$ D.C. CODE ANN. \$29-904a (Supp. 1956).

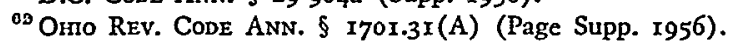

${ }^{63}$ Model Business Corporation ACt $\S 62$.

${ }^{04} I d . \$ 4 \mathrm{I}$. 
the assets in cash or in kind to the shareholders in partial liquidation. It is obvious that such a distribution involves an opinion of the board of directors that it is in the best interest of the shareholders to distribute some of the assets rather than to retain them in the business. The exercise of this authority, however, should be, and is, subject to a number of safeguards. In the Model Act, the restrictions are: that the corporation is not insolvent and would not be rendered insolvent by the distribution (a protection for the benefit of creditors); that the remaining net assets are not less than than the voluntary liquidation preference of the remaining preferred shares (a protection for the benefit of the holders of other preference shares); that all accrued cumulative dividends on preference shares have been paid (a further protection for all preferred shareholders); that authority for such a distribution is contained in the charter documents or approved by the vote of at least two-thirds of each class (assuring knowledge and consent by nonparticipating shareholders); and that disclosure of the source of the distribution accompany the distribution (to negative any inference that it is a distribution of profits). Such a distribution may be made out of stated capital or capital surplus under the Model Act. Every such distribution out of stated capital obviously is a reduction thereof, and no further corporate action is essential to make it effective.

Some interesting variations occur in the new statutes. The District of Columbia does not specify either stated capital or surplus as the source of distribution, but requires a two-thirds vote of each class for every distribution, apparently even if the charter permits. ${ }^{65}$ The distribution is limited to capital surplus in Texas, Pennsylvania, and North Carolina. ${ }^{66}$ Texas requires a two-thirds vote of each class of shares if that portion of capital surplus known as reduction surplus is used, and requires the board of directors to find that the distribution will not injure the corporation's ability to carry on its future business, if any is contemplated. Pennsylvania requires a majority vote of shareholders within one year prior to the distribution. North Carolina requires a majority vote, a pro rata distribution to the holders of the class receiving it, and the maintenance of assets at fair value at least equal to twice the liabilities of the corporation. Most of the other safeguards of the Model Act are adopted in the new statutes recognizing distribution in partial liquidation.

Under those statutes that limit a distribution in partial liquidation to capital surplus, if there is no capital-surplus in existence, it can be created by a reduction of stated capital by consent of the shareholders or by charter amendment. Otherwise, stated capital would be reduced by the distribution itself, and the class reduced would be the class to which distribution is made. This presents no problem where the class is without par value; but if par value shares are involved, a charter amendment reducing the par value seems inescapable.

${ }^{85}$ D.C. Code ANn. \$ 29-917a (Supp. 1956).

${ }^{\circ}$ Tex. Bus. CoRp. ACT art. 2.40(A)(I) and (2) (1956); PA. Stat. ANN. tit. 15, $\$ 2852-703$ (Supp. 1956); N.C. GeN. StaT. $\$ 55-50$ (c) (Supp. 1955). 
F. Reduction by Consent of Shareholders

As above noted, the board of directors can increase stated capital by transfer from surplus where no change of share structure is involved. Conversely, stated capital can be reduced where no share structure change is involved, but the action must be approved by the shareholders. All of the new statutes make provision for a reduction in this manner, the percentage of affirmative votes required varying from a majority of the class affected to two-thirds of each class. The filing of an official statement or certificate of reduction is always required as public notice to creditors and others of the action taken. ${ }^{67}$ An example of reduction by consent is suggested above as a step in preparation for the distribution in partial liquidation by creating or adding to capital surplus.

\section{G. Conversion and Exchange}

The problems incident to conversion and exchange in relation to capital and surplus have given some statutory revisors much concern and have resulted in some rather elaborate refinements. Where the convertible securities are of par value and conversions into shares of equal par value are authorized, the problem is simple; but the situation grows complex where shares without par value are involved and conversion requires the payment of some additional consideration or "boot."

A conversion or exchange of shares involves an issuance of shares and may result in an increase in stated capital. The Model Act provides a logical formula for determining the amount of consideration deemed to be received for the new shares. ${ }^{68}$ The consideration is the sum of (I) the stated capital then represented by the shares exchanged or converted; (2) that part of surplus, if any, transferred to stated capital upon the issuance of the new shares; and (3) any additional consideration paid to the corporation upon the issuance of the new shares. Shares without par value cannot be converted into par value shares, however, unless the stated capital then represented by the convertible shares is equal to the par value of the shares to be issued. In order to produce this equality, it may be necessary for the board of directors to transfer surplus to stated capital, as contemplated by clause (2) of the formula. It should be noted that the formula permits an increase, but not a decrease, in stated capital. This treatment of conversion and exchange has been adopted in all of the new statutes except Maryland, North Carolina, Ohio, and Pennsylvania. ${ }^{69}$

Maryland requires the price or consideration for the shares issuable on conversion to be fixed by the board of directors prior to the issuance of the convertible securities, and approval of shareholders is required under certain conditions. Provision is made for the conversion of obligations as well as shares. All shares acquired in conversion are deemed to be retired, and no proceedings are required to reduce

${ }^{o 7}$ Cf. Modez. Business Corporation Act $\$ 63 . \quad{ }^{88}$ Id. $\$$ I7.

${ }^{\circ \theta}$ MD. ANN. CODE art. 23, $\S \S 20$ and $33($ a) (z95I); N.C. GEN. STAT. $\$ 55-44(h)$ and $55-46($ c) (Supp. I955); OHo Rev. Code ANN. $\S \S$ r7or.21(B) and 1701.22(D). (Page Supp. r956); PA. Stat. ANN. tit. 15, $\S 2852-701$ (D) (Supp. 1956). 
stated capital by reason thereof. It seems to be an unnecessary refinement to consider that a conversion involves both a retirement of the old and issuance of the new, both decreasing and increasing stated capital, when, in reality, the new merely takes the place of the old, with possible adjustment for differences, if any.

Pennsylvania provides that shares may be acquired on conversion or exchange and that stated capital and capital surplus then represented by the shares so acquired may be applied for the purpose. The board of directors is required to cancel such shares, however, and file an official statement thereof.

In Ohio, both convertible shares and obligations may be issued, but if the par value of the shares issuable on conversion is greater than the stated capital or principal amount of the convertible securities, the corporation must have and reserve during the entire conversion period sufficient surplus solely for transfer to stated capital when and as conversions or exchanges take place. Unless convertible shares or obligations expressly provide that stated capital shall be increased or reduced, the stated capital of shares issued on conversion is the same as the shares or principal amount of obligations converted. The same principles apply to exchanges of securities.

North Carolina is similar to Ohio in many respects, but expressly forbids conversion into shares of greater par value than the face amount of obligations, or the par value of the shares converted, or the stated capital represented by shares without par value converted, unless there is a transfer from surplus to stated capital to cover the increase. The statute, then, adopts the formula of the Model Act.

In essence, any change in stated capital by reason of conversion or exchange is directly related to the basic elements above discussed. To illustrate, suppose that a twenty-five dollar par value preferred share is convertible into $2 \frac{1}{2}$ shares of five dollar par value common. Such a conversion, reducing the par value from twentyfive to twelve and one-half dollars, would occur only when the earnings on the common make it more attractive than the limited preferential dividend on the preferred. Under the Model Act, and the new statutes that have followed it, stated capital of the new common would equal the par value of the preferred, or double the par value of the common, in violation of the rule that par value alone is the stated capital of par value shares. Maryland is the only new statute that appears to provide for this eventuality, by treating the preferred share as retired, stated capital reduced by twenty-five dollars, and the common shares as a new issue increasing stated capital by twelve and one-half dollars. ${ }^{70}$ The net reduction would become capital surplus (reduction surplus in Texas). Possibly the accounting treatment under the other new statutes would be the same.

\section{H. Charter Amendment}

All of the new statutes, as well as the Model Act, ${ }^{71}$ contain liberal provisions for the reclassification of shares by charter amendment. The effect on stated capital

${ }^{70} \mathrm{MD}$. ANi. CODE art. 23, $\$ 20,33(\mathrm{a})$ and 24 (a) (1951).

${ }^{71}$ Model Business Corporation Act $\$ 53$. 
depends on the nature of the reclassification-increase or reduction in par value, change from par value to no par value or vice versa, change of one class into another, change of preferences within a class, and others. The amendment should make provision for its impact on the stated capital then representing outstanding shares. If it does not do so, it seems to follow that the foregoing principles respecting stated capital must be applied.

To recapitulate, stated capital under the new statutes is made up of (a) the par value of issued shares having a par value; (b) the consideration received for shares without par value not allocated to surplus; (c) amounts transferred from surplus upon payment of share dividends; (d) increases attributable to conversions, exchanges, and reclassifications of shares; (e) amounts transferred from surplus without a change of shares; (f) reductions attributable to the redemption or purchase of redeemable shares and the cancellation of other reacquired shares; $(\mathrm{g})$ reductions resulting from distributions in partial liquidation; and (h) reductions authorized by charter amendments or other consent of shareholders. As above noted, this summary is subject to some variations; nevertheless, it is the prevalent pattern in most of the new statutes.

The necessity for filing official statements of changes in stated capital, particularly of reductions, is recognized in virtually all modern statutes. Its main purpose is to provide public notice to creditors and others of the current status, from time to time, of the investments of the shareholders in the corporate enterprise. It may be largely ineffective for the purpose, but it satisfies the idea that the information should be available somewhere other than in the office of the corporation itself.

We turn next to surplus, its several kinds, computations, and uses.

\section{III}

\section{SurPLUS}

The concept of surplus under modern corporation statutes and practices must be viewed in the light of developments in the concept of capital and divorced from the simple doctrine of early laws that it was synonymous with profits. In present usage, it is a mixture of profits and amounts that in former years would have been capital.

In all of the new statutes, as in the Model $\mathrm{Act}^{72}$ two kinds of surplus are recognized-earned surplus and capital (or paid-in) surplus. Texas injects a third kindreduction surplus, which other states include in capital surplus; ${ }^{73}$ and Wisconsin provides for a portion of capital surplus by the title "net capital surplus."74

In preparing the Model Act, the American Bar Association Committee found it desirable to employ a term that would include both capital and earned surplus to avoid repetition where both were referred to in some provisions of the Act. The

\footnotetext{
7. Id. $\$ 2$.

73 TeX Bus. CoRp. ACr art. I.02(A) (14) (1956).

${ }^{24}$ Wis. Stat. $\$$ I80.02(I3) (I955).
} 
term "surplus" is there defined as the excess of net assets over stated capital. ${ }^{75}$ Thus, the existence of surplus depends upon there being something left over after making full provision for creditors (net assets) and the permanent investment of shareholders (stated capital). This approach has been adopted in all of the new statutes, except in Wisconsin, Maryland, and the District of Columbia, which found it unnecessary separately to define surplus as an over-all term.

In the discussion which follows, the determination and uses of the component parts of surplus will be largely confined to the general import of the new statutes, because a detailed description of some of the variations among them would be too tedious for an article of this length. For this purpose, the subject is broken down into earned surplus, capital surplus, and dividends.

\section{A. Earned Surplus}

No term in the area of corporation law and practice has given rise to so many conflicting opinions as has the term earned surplus. Everyone seems to know what it means, until an attempt is made to define, it; then, it is challenged as inaccurate, or impractical, or ambiguous, or deceptive, or otherwise deficient. The committee that prepared the Model Act believed that it could be defined and did so by describing it as the balance of net profits, income, gains, and losses from the date of incorporation, or from the latest date when a deficit was eliminated by the application of capital surplus or stated capital or otherwise, after deducting subsequent distributions to shareholders and transfers to stated capital and capital surplus to the extent made out of earned surplus. ${ }^{78}$ This definition is intended to reflect the net cumulative balance of profits and losses historically determined. In as much as the Act exonerates directors from liability, however, when they act in good faith upon financial statements represented to them to be correct by an appropriate officer or public accountant, and consider the assets to be of their book value, ${ }^{77}$ they can rely on the balance sheet as evidence of the historical earnings and profits if they act in good faith.

The Model Act definition was adopted after conferences with the Committee on Terminology of the American Institute of Accountants. It was recognized that the accounting profession was discarding the term "earned surplus" in favor of such terms as "retained income," "retained earnings," "accumulated earnings," or "earnings retained for use in the business." The American Bar Association Committee was of the view that "surplus" had come into disrepute among accountants because it had not been legally defined, that it could be defined by statute in an accounting sense, and that there was no substantial difference between surplus as defined in the Model Act and the substitute terms proposed by the accountants for their own use. The accountants' committee conceded that the term "earned surplus" was more appropriate in a statute; hence, its use in the Model Act.

The definition of earned surplus proposed in the Model Act has been adopted

${ }^{75}$ MOdeL BUStNess CoRporatton Acr $\$ 2$.

"7. $1 d .543$. 
in Oregon, Texas, Virginia, and North Dakota, ${ }^{78}$ and with modifications in Wisconsin, North Carolina, and Ohio. ${ }^{79}$ Maryland and the District of Columbia use the term, but do not specifically define it. Wisconsin excludes profits from transactions in a corporation's own shares and losses thereon charged to capital surplus. Ohio is the same, but with a slight twist in the treatment of losses on such transactions, which may be charged to earned surplus only after absorbing gains from such transactions credited to capital surplus.

Pennsylvania is the outstanding exception to the trend adopted in the other new statutes. $^{80}$ In a recent amendment, the distinction between earned surplus and capital surplus has been reversed. Capital surplus is defined in a positive sense, and the balance of surplus is earned surplus. This change in viewpoint is attributed to the alleged practical difficulty of determining earned surplus historically and the possible liability of directors for errors in the determination. Apparently, Pennsylvania prefers to determine earned surplus by deducting from assets the claims of creditors, stated capital, and capital surplus. It is extremely doubtful that statutory revisors and accountants generally will accept the idea that earned surplus is a residue of assets, instead of a cumulative balance of profits retained in the business. ${ }^{81}$

Under the Model Act and those new statutes that have adopted its definition, transactions in a corporation's own shares affect earned surplus, while in Wisconsin and Ohio, the primary effect is on capital surplus.. The choice may be one of personal preference, but doubtlessly is based upon conservative accounting opinion that gains and losses on such transactions should be matched through capital surplus, and only net losses charged against earned surplus.

As to unrealized appreciation, some members of the American Bar Association Committee maintain that such appreciation is properly includable in earned surplus and thus available for dividends generally. Others, including the writer, believe that unrealized appreciation should be included in earned surplus, but available only for share dividends. ${ }^{82}$

Earned surplus is generally available for the payment of dividends in cash, property, or a corporation's own shares; for transfer to capital surplus or stated capital; and for the repurchase of shares of the corporation. There are exceptions and conditions to each use, as was previously explained above under Stated Capital or as will be explained below under Dividends, which need not be repeated at this point.

${ }^{78}$ Ore. Rev. Stat. $\$ 57.004$ (S) (Supp. r955); TEx. Bus. CoRp. Act art. I.02(A)(13) (r956); VA. Code ANN. \$13.I-3(i) (Supp. 1956); N.D. Laws I957, c. 102, \& 2(I2).

${ }^{79}$ Wis. Stat. $\S 180.02$ (II) (1955); N.C. Gen. Stat. $\$ 55-49$ (d) (Supp. r956); OHo Rev. Code ANN. \& 1701.32(A) (Page Supp. 1956).

${ }^{80}$ P. STAT. ANN. tit. I5, \$ 2852-2 (Supp. 1956).

${ }^{81}$ Compare Seward, Earned Surplus-Its Meaning and Use in the Model Business Corporation Act, 38 VA. L. Rev. 435 (1952), with Hackney, The Financial Provisions of the Model Business Corporation Act, 70 Harv. L. REv. 1357 (1957).

${ }^{85}$ See Seward, supra note 81, at 440, and Carrington, Experience in Texas with the Model Business Corporation Act, 5 UTAH L. REv. 292, 296 (1957). 


\section{B. Capital Surplus}

In the Model Act, all surplus is capital surplus, unless it falls within the definition of earned surplus. ${ }^{83}$ Capital surplus may arise from four sources: premium received on the sale of par value shares, allocation of part of the consideration received for shares without par value, reduction of stated capital, and transfer from earned surplus, all of which have been referred to above under Stated Capital.

This definition appears in all of the new statutes, except Wisconsin, Maryland, and the District of Columbia, but with additions or variations in some of them. Contributions of property to the corporation are expressly included in Ohio and Pennsylvania. ${ }^{84}$ Appreciation surplus is included in Ohio (appreciation in the fair value of physical assets over the amount carried on the books), Pennsylvania (unrealized appreciation), and North Carolina (resulting from a good faith revaluation upon a "demonstrably adequate basis"). ${ }^{85}$ The sale of treasury shares in excess of cost or the retirement of such shares at less than stated value is capital surplus in North Carolina. ${ }^{86}$ North Carolina also includes "paid-in surplus," which term is used in the District of Columbia in lieu of capital surplus. ${ }^{87}$ Texas specifies that surplus resulting in a reduction of stated capital shall be "reduction surplus," a term adopted from the current California statute. ${ }^{88}$ Maryland provides no definition, but appears to use the term in the same sense as paid-in surplus in the District of Columbia.

Wisconsin has indulged in some accounting refinements. It defines capital surplus as the excess of the sum of stated capital and the cost of treasury shares over the sum of stated capital and earned surplus. If there is a deficit in earned surplus, it must be deducted, and the remainder of capital surplus becomes "net capital surplus." 88

Capital surplus is a more inclusive term than paid-in surplus, which implies that it is limited to part of the consideration received for issued shares. Also, capital surplus seems to be more acceptable to the accounting profession, because it bears more resemblance to capital than earnings and profits and covers a variety of surplus terms previously in use.

Capital surplus is generally available for certain limited purposes: for distributions in partial liquidation and transfers to stated capital, as previously explained, for cash or property dividends on cumulative preference shares when authorized by charter or a specified percentage of shareholders, for purchases of a corporation's own shares in some cases, and for the reduction or elimination of certain losses or

${ }^{83}$ Model Business Corporation Act $\$ 2$. 1956).

${ }^{84}$ Omo Rev. Stat. ANn. $\$$ I701.32(c) (Page Supp. 1956); Pa. Stat. ANn. tit. 15, $\$ 2852-2$ (Supp.

${ }^{85}$ Oho Rev. Stat. ANn. $\$$ I70I.32(B) and (D) (Page Supp. 1956); Pa. Stat. ANn. $\$ 2852-2$ (Supp.

I956); N.C. Gen. Stat. \$55-49(e) (Supp. 1955).

${ }^{80}$ N.C. Gen. Stat. \$55-49(f) (Supp. I955).

${ }^{87}$ Id. \$ 55-49(e); cf. D.C. CODE ANN. \$ 29-902(k) (Supp. 1956).

${ }^{88}$ Tex. Bus. Corp. ACr art. T.02(A) (14) (1956); of. Car. Corp. Code $\$ 1906$.

${ }^{89}$ WIs. STAT. $\S 180.02$ (12) and (13) (1955). 
a deficit in earned surplus. This last mentioned use is generally available only after earned surplus has been exhausted, in accordance with the conservative accounting principle of applying losses against earned surplus before anything of a capital nature can be applied. In the definition of earned surplus in the Model $\mathrm{Act}^{90}$ and the new statutes that have adopted it, any determination of earned surplus begins with such application, because all prior accumulations have been wiped out.

\section{Dividends}

All of the new statutes, and the Model Act, ${ }^{91}$ authorize the payment of dividends in cash, property, or the corporation's own shares, but there are variations in the source and conditions attached to dividends among the statutes.

Cash and property dividends are payable out of earned surplus in all of the new statutes; and in North Carolina, also out of net profits during the current or next preceding accounting period (not less than six or more than twelve months), regardless of the impairment of stated capital-or, in other words, a deficit in surplus. $^{92}$ The payment of dividends out of current profits when there is no earned surplus, although recognized in Delaware and a few other states, ${ }^{93}$ is regarded as deceptive by the American Bar Association Committee and the revisors of most of the new statutes. It is not found in the Model Act.

The payment of cash or property dividends is restricted in a number of ways. It is elementary that dividends should not be paid contrary to charter provisions, or on any class of shares in derogation of the rights and preferences of the shares of other classes, or when the corporation is insolvent or would be rendered insolvent by the payment. Under statutes that restrict earned surplus pending cancellation or other disposition of treasury shares, dividends should be and are limited to earned surplus not so restricted. Practically all of the new statutes permit the board of directors to establish and abolish reserves, in which case dividends are also limited to the earned surplus not so reserved. A "net asset" test is sometimes applied by prohibiting a dividend that would reduce the remaining net assets below the liquidation preferences of preferred shares; but this restriction is unnecessary where the Model Act definitions have been adopted, because the maintenance of such preferences is protected in the determination of stated capital, without which there is no surplus.

Most of the new statutes recognize the status of wasting-assets corporations and permit dividends to be paid in cash or property without deduction from earned surplus of depletion and depreciation upon disclosure of the source. This is equivalent to payment out of depletion and depreciation reserves.

Share dividends are usually payable out of authorized but unissued shares, requiring a transfer from surplus to stated capital, or out of treasury shares, the latter

${ }^{\circ 0}$ Model Business Corporation Act $\S 2$.

${ }^{2}$ N.C. Gen. StAT. $\$ 55-50(2)$ (Supp. 1955).

${ }^{21} I d . \S 40$.

${ }^{03}$ E.g., Del. Code AnN. tit. 8, $\S$ I70(a) (1953); CaI. Corp. Cade $\S$ I500(b); Minn. Stat. $\S$ $301.22(3)$ (1953). 
not to be identified as a dividend in North Carolina.94 In several states, as in the Model Act, ${ }^{95}$ treasury shares may be used only if they have been acquired out of surplus; and in some states, a share dividend cannot be paid on shares of another class unless authorized by the charter or the vote of a specified percentage of shares of the class in which payment is to be made. In Ohio, only a share dividend can be paid out of surplus arising from unrealized appreciation or revaluation of assets..$^{00}$ In Ohio, a share dividend payable in treasury shares requires the same transfer from surplus to stated capital as if paid in authorized but unissued shares, because stated capital is automatically reduced when the shares are reacquired. ${ }^{97}$

Cash or property dividends are payable out of capital surplus to a very limited degree. The most common provision is permission to pay a cash dividend in discharge of cumulative dividends on preference shares when no earned surplus is available and when insolvency neither exists nor results. Authority is usually required in the charter or by vote of a specified percentage of shares. In North Carolina, cash or property dividends are payable out of capital surplus under such circumstances, except that capital surplus paid in by one class of shares cannot be used to pay a dividend on a junior class. ${ }^{88}$ In Virginia, the only restriction is disclosure of the source; ${ }^{99}$ in fact, disclosure is generally required in all of the new statutes when capital surplus is used for dividend purposes.

Paid-in surplus in the District of Columbia is usable for distributions in partial liquidation and for preferential dividends with disclosure. ${ }^{\mathbf{1 0 0}}$ The same is true as to net capital surplus in Wisconsin, except that it is usable for preferential dividends only if there is no earned surplus. ${ }^{101}$ Distributions in partial liquidation have been discussed above under Stated Capital.

\section{IV}

\section{LraBIIITY}

The new statutes are practically uniform in holding directors liable if they assent to the payment of any dividend or the making of any distribution or the purchase of any of the corporation's own shares in violation of the provisions of the statute. Directors who thus become liable have a right of contribution against other directors who are also liable. Assent is often presumed if a director is present at a meeting where the questionable action is taken and does not dissent then or promptly thereafter.

As previously noted, the Model $\mathrm{Act}^{102}$ and the new statutes that follow it exonerate directors if in good faith they rely on financial statements submitted by an appropriate officer of the corporation or independent accountants, and if, in like

o N.C. Gen. Stat. $\$ 55-51$ (d) (Supp. 1955). $\quad{ }^{\circ 0}$ Model Business Corporation Act $\$ 40$.

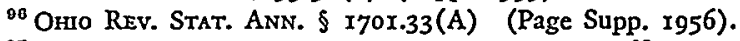

${ }^{97} I d$. $\$$ I 70I.3I (A).

${ }^{88}$ N.C. Gen. STAT. $\$ 55-50$ (a)(3) (Supp. 1955).

${ }^{\circ 0}$ VA. CODE ANN. § I3.I-43(a) (Supp. r956).

${ }^{100}$ D.C. Code ANN. $\$ 29-917$ (b) and 29-917a(d) (Supp. I956).

101 Wis. Stat. $\& 180.38(2)(a)$ and I80.38(3) (I955).

${ }^{102}$ Modez Business Corporation Act $\$ 43$. 
manner, they assume that the corporate assets are of book value. This exoneration protects directors, who usually are not the bookkeepers, from being absolute guarantors of corporate action. It is true that some statutes seek to put directors on constant inquiry as to values and liabilities far beyond the exoneration just described; but the writer regards such responsibility as a strong and needless deterrent. Good faith reliance on others governs most of our business dealings and sets a standard of conduct that facilitates rather than impedes the availability of able directors. In contrast to North Carolina, Texas allows a director the right to rely on an opinion of independent counsel ${ }^{103}$ - a precedent the Model Act and the other new statutes have not yet adopted.

In addition to the liability of directors, many of the new statutes permit a corporation to recover any unlawful dividend or other distribution knowingly received by shareholders. This is based upon a homely principle that if a shareholder knows he should not have received the same, he should return it.

\section{Conceusion}

The foregoing technical review of the ten most recent revisions of business corporation statutes, as well as of the Model Act, illustrates the statutory trend in respect of capital and surplus and the many ways in which statutory revisors can vary details within the basic principles of the trend. The fundamental concepts of capital and surplus are essentially the same in all of the new statutes; the variations are in relatively minor matters, reflecting local policies, precedents, and traditions.

Uniformity among the states appeals to reason as an ultimate aim, but there is little prospect of complete uniformity in the area of corporation law in the near future. Each jurisdiction approaching a revision of its corporate statute is deeply conscious of its sovereignty and freedom of choice. In exercising this freedom, it selects from its own past and from other jurisdictions what it believes to be the best policy for the artificial beings created pursuant to its laws. Very few statutes have the attribute of originality; the draftsmen look about to see what others have done, select what they like, and impose their personal views. Then, the legislators superimpose their own ideas of policy and politics. Thus, when similarities appear, it is a tribute to the soundness of principle. Such is the case with the new statutes here reviewed. The striking thing is that they are so nearly alike, not that they are so different, when the drafting and legislative processes are considered.

In the deliberate way in which our state governments are accustomed to proceed, there may yet appear a larger degree of uniformity than previously known in expressing the statutory law affecting the rights of shareholders in the financial structure of modern business corporations. If the Model Act contributes to this result, it will have served its purpose exceedingly well.

${ }^{103}$ TEX. Bus. CoRp. LAw art. 2.4 r (D) (1956). 